\title{
Proses Berpikir Mahasiswa Dalam Menyelesaikan Masalah Berstandar PISA (Programme for International Student Assessment)
}

\author{
1Maryono \\ Program Studi Tadris Matematika Fakultas Tarbiyah dan Ilmu Keguruan (FTIK) \\ Institut Agama Islam Negeri (IAIN) Tulungagung \\ Email:mario_stain@yahoo.com
}

\begin{abstract}
One way to measure the development of a country in the main international scale assessment is the PISA (Programme International for Student Assesment). The thinking process of students in solving PISA standard problems can be analyzed using the theory of Assimilation and Accommodation. The approach used in this study is qualitative with the type of case study. The data analyzed in the form of the results of the subject's work when solving problems with PISA standards and the results of interviews with the research subjects. The subject of this study was a prospective student of mathematics at IAIN Tulungagung. The results of the study indicate that the thinking process of students when solving PISA standard problems includes: (a) assimilation: that is, students can directly apply their knowledge to the problems to obtain solutions to problems; and (b) accommodation: i.e. students modify their knowledge to be adapted to existing problems and form new knowledge to suit existing problems.
\end{abstract}

Keyword: thinking process, assimilation, accommodation, Polya problem solving, PISA standard problems.

\begin{abstract}
Abstrak: Salah satu cara untuk mengukur perkembangan suatu negara dalam penilaian utama berskala internasional adalah PISA (Programme International for Student Assesment). Proses berpikir siswa dalam menyelesaikan masalah berstandar PISA bisa dianalisis menggunakan teori Asimilasi dan Akomodasi. Pendekatan yang digunakan dalam penelitian ini adalah kualitatif dengan jenis studi kasus. Data yang dianalisis berupa hasil pekerjaan subjek pada saat menyelesaikan masalah berstandar PISA dan hasil wawancara terhadap subjek penelitian. Subjek penelitian ini adalah mahasiswa calon guru matematika di IAIN Tulungagung. Hasil penelitian menunjukkan bahwa proses berpikir mahasiswa ketika menyelesaikan masalah berstandar PISA meliputi: (a) asimilasi: yaitu mahasiswa dapat menerapkan secara langsung pengetahuan yang dimilikinya dengan masalah yang ada untuk memperoleh solusi permasalahan; dan (b) akomodasi: yaitu mahasiswa memodifikasi pengeta-huan yang dimilikinya untuk disesuaikan dengan masalah yang ada serta membentuk pengetahuan baru untuk disesuaikan dengan masalah yang ada.
\end{abstract}

Kata Kunci: proses berpikir, asimilasi, akomodasi, pemecahan masalah Polya, masalah berstandar PISA.

\section{PENDAHULUAN}

Literasi merupakan suatu istilah yang biasanya dihubungkan dengan huruf atau aksara. Literasi merupakan kata serapan yang diambil dari kata dalam bahasa Inggris yaitu literacy, yang diartikan sebagai kemampuan untuk membaca dan menulis. Salah satu bidang yang menyerap istilah literasi adalah matematika, sehingga terdapat istilah literasi matematika. Sebagian pendapat menyebutkan bahwa matematika merupakan bahasa simbol atau bilangan. Pada umumnya masyarakat menganggap matematika selalu berkaitan dengan angka (bilangan) atau operasi hitung, di antaranya: penjumlahan, 
pengurangan, perkalian, dan pembagian. Padahal, definisi matematika bisa jauh lebih luas dari sekedar ilmu bilangan dan berhitung. Dalam matematika kompetensi biasanya dihubungkan dengan kemampuan untuk memanipulasi bilangan, antara lain kemampuan untuk menghitung secara cepat. Pengertian tersebut sebenarnya tidak keliru, tetapi kurang lengkap. Memang benar bahwa salah satu aspek dari literasi matematika adalah kompetensi menghitung. Namun, bilangan sebenarnya hanya sebagian kecil dari objek matematika yang sangat luas.

Pada saat ini, kalkulator dan komputer telah banyak digunakan, sehingga kecepatan dalam menghitung tidak lagi menjadi tujuan utama. Secepat apapun seseorang dalam berhitung, ada kalkulator dan komputer yang bisa menggantikan dengan proses yang mungkin lebih cepat. "Dalam kehidupan modern ini kompetensi membaca, menulis, dan menghitung, merupakan kompetensi yang masih dianggap penting, tetapi tidaklah cukup" (Whardani dan Rumiati, 2011). "Literasi matematika merupakan kemampuan seorang individu dalam mengidentifikasi dan memahami manfaat dan kegunaan matematika di dunia, untuk dijadikan sebagai dasar dalam mengaplikasikan dan melibatkan diri dengan matematika sesuai dengan apa yang dibutuhkan siswa sebagai warga negara dalam membangun, peduli, dan reflektif" (OECD, 2012). Kualitas pendidikan biasanya dijadikan sebagai alat ukur perkembangan suatu negara (Johar, 2012). Untuk menggambarkan baik tidaknya kualitas pendidikan khusus untuk siswa usia wajib belajar (SD sampai kelas 3 SMP), bisa dilihat dari kemampuan siswa dalam menyelesaikan masalah matematika, sains, dan membaca beserta aplikasinya dalam kehidupan sehari-hari.

Salah satu alat untuk mengukur perkembangan suatu negara dalam penilaian berskala internasinoal adalah PISA. Menurut Hayat dan Yusuf (2010) "PISA (Programme International for Student Assesment) bertujuan menilai dan meneliti secara periodik dan tentang kemampuan siswa yang berusia 15 tahun (kelas IX SMP atau kelas X SMA) dalam membaca (reading literacy), matematika (mathematics literacy), dan IPA (scientific literacy)." "Tujuan utama dari PISA adalah literasi yang menitikberatkan pada keterampilan dan kompetensi siswa yang diperoleh dari bangku sekolah dan dapat aplikasikan dalam kehidupan sehari-hari dan dalam berbagai konteks (Johar, 2012)." Pada pelaksanaannya PISA disponsori oleh negara-negara maju dan sedang berkembang yang tergabung dalam OECD (The Organization for Economic Cooperation and Development). Indonesia mulai berpartispasi dalam kegiatan PISA sejak pertama kali diselenggarakan oleh OECD tahun 2000. Namun prestasi Indonesia masih jauh dibandingkan dengan peserta dari negaranegara lain. Setiap negara memang memiliki sistem pendidikan yang berbeda-beda untuk mampu bersaing dengan negara lain. Oleh sebab itu, mengacu hasil PISA tersebut, maka diperlukan evaluasi terhadap sistem pendidikan di Indonesia. Lahirnya kurikulum 2013 salah satunya dipengaruhi oleh perkembangan pendidikan di tingkat internasional. Materi uji yang ditanyakan dalam PISA tidak terdapat di dalam kurikulum Indonesia sebelumnya (sebelum lahirnya Kurikulum 2013).

Faktor lain yang mempengaruhi rendahnya peringkat negara Indonesia pada PISA adalah kurangnya latihan masalah berstandar PISA yang diberikan oleh guru pada saat pembelajaran di kelas. Hal ini kemungkinan disebabkan kurangnya pengetahuan guru matematika tentang masalah-masalah berstandar PISA. Mahasiswa program studi Tadris Matematika sebagai calon guru yang nantinya akan mewarnai perkembangan pendidikan matematika di masa yang akan datang perlu untuk dibekali pengetahuan tentang masalah berstandar PISA. Oleh karena itu untuk mengawali analisis kebutuhan lebih lanjut perlu ditelusuri bagaimana proses berpikir mahasiswa ketika diberikan masalah berstandar PISA.

Definisi tentang masalah telah dikemukakan oleh beberapa ahli, di antaranya Grouws (dalam Nuralam, 2009) menyebutkan bahwa masalah dalam matematika adalah 
segala sesuatu yang menuntut kita untuk mengerjakannya. Sedangkan menurut Hudojo (1988) suatu soal merupakan suatu masalah bagi seseorang jika tidak segera ditemukan aturan atau hukum tertentu untuk menemukan jawaban soal tersebut. Kemudian Krulik dan Rudnick menyatakan bahwa "problem is a situation, quantitative or otherwise, that confronts an individual or group of individuals, that requires resolution, and for which the individual sees no apparent or obvious means or path to obtaining a solution". (Carson, 2007). Berdasarkan beberapa pendapat di atas, masalah yang dimaksud dalam penelitian ini ialah suatu keadaan dimana mahasiswa belum mengetahui atau menemukan metode (teknik/cara) untuk menjawab soal dan ia membutuhkan langkah-langkah untuk dapat menyelesaikannya.

Suatu masalah pada umumnya memuat situasi yang mendorong seseorang untuk menyelesaikannya, akan tetapi belum ditemukan secara langsung metode atau teknik apa yang harus dipilih untuk menyelesaikannya. Jika suatu masalah diberikan kepada seorang mahasiswa dan mahasiswa tersebut langsung mengetahui cara menyelesaikannya dengan benar, maka soal tersebut tidak dapat dikatakan suatu masalah. "Padahal pemecahan masalah dalam matematika merupakan salah cara yang baik untuk meningkatkan kemampuan penguasaan materi. Gagne memposisikan problem solving sebagai keterampilan intelektual paling tinggi dari hirarki keterampilan intelektual. Karena dalam pemecahan masalah terjadi bentuk pembelajaran yang lebih kompleks dan membutuhkan aturan-aturan yang lebih sederhana yang harus diketahui sebelumnya oleh mahasiswa" (Ketut Suma dkk., 2007). Selanjutnya Hembree (dalam Lazakidou, 2007) menyatakan bahwa "problem solving is characterised as an essential and complex activity in mathematics". Selain itu beberapa sumber lain menyatakan "Problem solving is the foundation of much mathematical activity. It is so important that the National Council of Teachers of Mathematics (NCTM) has identified it as one of the five fundamental mathematical process standards" NCTM (dalam Zhu, 2007). Oleh karena itu para ahli pendidikan matematika banyak melakukan usaha untuk meningkatkan kompetensi mahasiswa dalam memecahkan atau menyelesaikan masalah. Jadi pemecahan masalah merupakan alat yang digunakan untuk mengubah dari keadaan yang dihadapi menjadi keadaan yang diinginkan, yaitu terselesaikannya masalah tersebut..

Salah satu acuan yang digunakan dalam langkah-langkah pemecahan masalah adalah yang sebagimana yang dikemukakan oleh Polya yang terdiri dari empat langkah, yaitu: "menganalisis dan memahami masalah (analyzing and understanding a problem); merancang dan merencanakan penyelesaian (designing and planning a solution); mencari penyelesaian dari masalah (exploring solution to difficult problem); dan memeriksa penyelesaian (verifying a solution)."

Pada saat terjadi pembelajaran terutama ketika mahasiswa memecahkan masalah tentunya terjadi proses berpikir, karena pada saat itu terjadi aktivitas mental. "Seseorang dikatakan berpikir jika orang tersebut melakukan kegiatan mental. Proses berpikir adalah aktivitas yang terjadi di dalam otak manusia. Ketika berpikir, orang menyusun hubungan antara bagian pengetahuan yang telah dimiliki atau direkam, kemudian hasil rekamanrekaman tersebut dianggap sebagai definisi-definisi yang kemudian digunakan untuk dapat menyelesaikan masalah yang diberikan. Selama menyelesaikan masalah siswa melakukan proses berpikir dalam benak sehingga ditemukan jawaban atas masalah tersebut. Salah satu peran pendidik dalam pembelajaran matematika adalah memfasilitasi peserta didik untuk mengungkapkan bagaimana proses yang terjadi dalam pikirannya ketika menyelesaikan suatu masalah, misalnya dengan cara meminta peserta didik menceritakan langkah yang ada dalam pikirannya" (Yulaelawati, 2004). Hal ini dilakukan untuk mengeksplorasi kesalahan berpikir yang dialami dan merapikan struktur pengetahuannya. Di samping peran di atas, menurut Dewiyani (2008) pendidik juga berperan menciptakan kondisi pembelajaran yang mampu membiasakan peserta didik 
untuk melakukan penyelidikan dan penemuan. "Proses berpikir itu pada prinsipnya terdapat tiga langkah, yaitu pembentukan pengertian, pembentukan pendapat, dan pembentukan keputusan atau penarikan kesimpulan" (Suryabrata, 2004). Ketiga proses tersebut bisa diuraikan sebagai berikut: "proses pembentukan pengertian, yaitu menghilangkan ciri-ciri umum dari suatu sehingga tinggal ciri khas dari sesuatu tersebut; pembentukan pendapat, yaitu pikiran menggabungkan (menguraikan) beberapa pengertian, sehingga menjadi tanda masalah; pembentukan keputusan atau pembentukan kesimpulan, yaitu pikiran menggabung-gabungkan pendapat dan menarik keputusan dari keputusan yang lain."

Penelitian ini difokuskan pada proses berpikir mahasiswa yang meliputi asimilasi dan akomodasi dalam menyelesaikan masalah berstandar PISA dengan mengikuti langkah-langkah pemecahan masalah model Polya.

\section{METODE}

Pendekatan yang digunakan dalam penelitian ini adalah kualitatif, karena sesuai karakteristik penelitian kualitatif. Sedangkan jenis penelitian yang yang digunakan dalam penelitian ini adalah studi kasus.

Penelitian ini dilaksanakan di Jurusan Tadris Matematika Fakultas Tarbiyah dan Ilmu Keguruan Institut Agama Islam Negeri (IAIN) Tulungagung yang beralamatkan di Jalan Mayor Sujadi Timur Nomor 46 Desa Plosokandang Kecamatan Kedungwaru Kabupaten Tulungagung. Lokasi ini dipilih karena berdasarkan studi pendahuluan yang dilakukan, banyak mahasiswa yang masih merasa asing dengan soal-soal berstandar PISA.

Data yang akan dikumpulkan berupa: (1) hasil pekerjaan mahasiswa dalam menyelesaikan masalah yang berstandar PISA dan (2) Kumpulan data atau pernyataan verbal dari mahasiswa yang diperoleh dari hasil wawancara antara peneliti dengan subjek penelitian; Sedangkan sumber data dalam penelitian ini adalah mahasiswa IAIN Tulungagung Jurusan Tadris Matematika semester 4.

Hasil pengumpulan data selanjunya dianalisis berdasarkan tahap-tahap yang dikembangkan oleh Creswell (2012). Tahap analisis data yang dikembangkan oleh Creswell (2012) saling berhubungan dan tidak harus selalu sesuai dengan susunan yang disajikan. Uraian analisis data dalam penelitian ini sebagai berikut: (1) Mengolah dan mempersiapkan data untuk dianalisis, (2) Membaca keseluruhan data, (3) Menganalisis lebih detail dengan mengcoding data, (4) Menerapkan proses coding untuk mendeskripsikan kategori dan tema, (5) Menghubungkan tema-tema/deskripsi, (6) Menginterpretasi atau memaknai data

\section{HASIL DAN PEMBAHASAN}

Pada bagian ini akan dipaparkan bagaimana proses berpikir subjek (menggunakan Teori asimilasi dan akomodasi dari Piaget) dalam menyelesaikan masalah berstandar PISA (Programme International for Student Assesment) menggunakan langkahlangkah sesuai pendapat Polya. Data yang dianalisis dalam penelitian ini meliputi hasil tes mengenai masalah berstandar PISA sebanyak 2 masalah dan hasil wawancara dengan subjek. Pada paparan ini akan disajikan hasil analisis data secara kualitatif dan disusun berdasarkan urutan subjek.

\section{Subjek 1 (S1)}

Masalah 1

Pada masalah 1 ini subjek dituntut untuk menentukan sketsa lintasan (track) pada balapan mobil berdasarkan grafik jarak terhadap kecepatan yang disajikan pada soal. 
Memahami Masalah

Untuk mengetahui proses berpikir S1 dalam memahami masalah, maka peneliti melakukan wawancara dengan subjek, dan berikut adalah hasil petikan wawancaranya.
$P \quad: \quad$ Coba jelaskan apa yang kamu pikirkan ketika diberikan grafik seperti itu
S1 : Jujur saja saya berpikiran bahwa grafik kecepatan konstan akan terjadi pada jalan lurus, dan sebaliknya jalan yang lurus pasti grafik kecepatannnya konstan.
$P \quad: \quad$ Iya, terus bagaimana selanjutnya?
S1 : Tapi setelah mendapat penjelasan dari Bapak tadi bahwa pada track lurus bisa saja kecepatan naik dulu lalu konstan. Trus saya juga berkeyakinan bahwa kecepatan akan naik jika jalannya tanjakan.
$P \quad$ : Lho kok bisa? Bukannya jalan tanjakan kecepatan malah menurun. Nah berarti sampeyan menganggap grafik itu menunjukkan tekstur jalan ya?
S1 : Iya Pak. Hehehe...

Berdasarkan petikan tersebut, terlihat bahwa S1 mengalami kesalahan persepsi mengenai grafik yang diberikan. S1 menganggap bahwa pada track lurus kecepatan mobil balap selalu konstan, padahal pada track lurus ada kemungkinan kecepatan mobil naik (setelah belokan) dan turun (sebelum belokan). Di sini terlihat bahwa S1 mengalami proses akomodasi, karena S1 belum mampu menghubungkan skema yang sudah ada (mengenai grafik fungsi) dengan skema yang baru (membaca grafik fungsi). Tetapi setelah peneliti memberikan beberapa petunjuk, S1 bisa membaca dan memahami grafik yang diberikan.

\section{Merencanakan Strategi}

Pada tahap ini peneliti mengeksplorasi proses berpikir S1 sebagaimana petikan wawancara berikut.

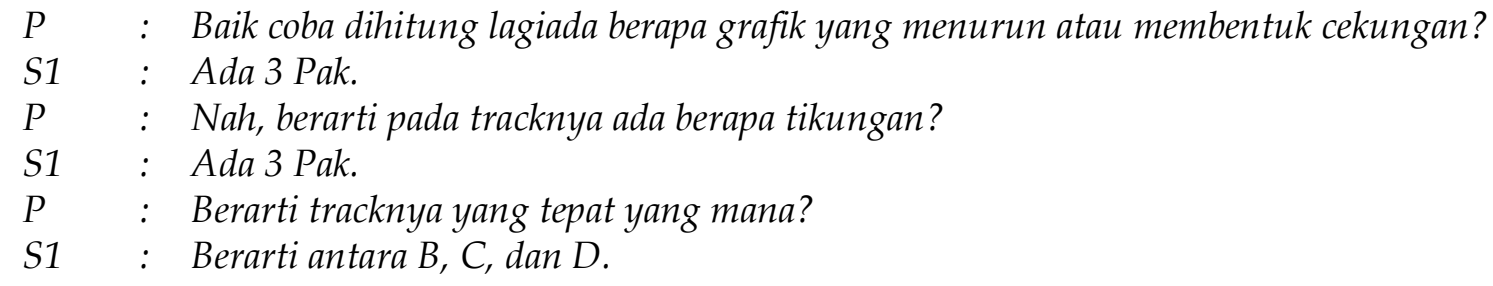

Karena pada tahap sebelumnya S1 sudah bisa mulai memahami dan membaca grafik (dengan petunjuk) sehingga S1 sudah mampu menentukan banyaknya tikungan pada track berdasarkan grafik, yaitu dengan menghitung banyaknya cekungan. Bahkan S1 juga bisa menentukan jawaban (track) yang mungkin untuk grafik yang diberikan. Hal ini menunjukkan bahwa pada tahap ini S1 mengalami proses asimilasi.

\section{Melaksanakan Strategi}

Berikut adalah jawaban tertulis S1 untuk masalah nomor 1.

\begin{tabular}{l} 
Karena mobil kecepatannya turun sebanyat 3 kali, jodi oda 3 kali belokan \\
\hline dan kecepatan mobil naik 3 kali dan konstan pada 3 perlintasan \\
\hline
\end{tabular}

\section{Gambar 1. Jawaban S1 untuk soal nomor 1}

Sesuai dengan hasil analisis proses berpikir pada tahap memahami masalah, yaitu S1 mengalami akomodasi pada struktur kognitifnya, maka penyelesaian yang dituliskan S1 juga terjadi kesalahan. Sebenarnya alasan yang diberikan S1 sudah tepat, tetapi grafik 
yang yang dipilih masih kurang tepat. Oleh karena itu peneliti ingin mengeksplorasi proses berpikir S1 pada tahap ini melalui wawancara sebagaimana petikan berikut.

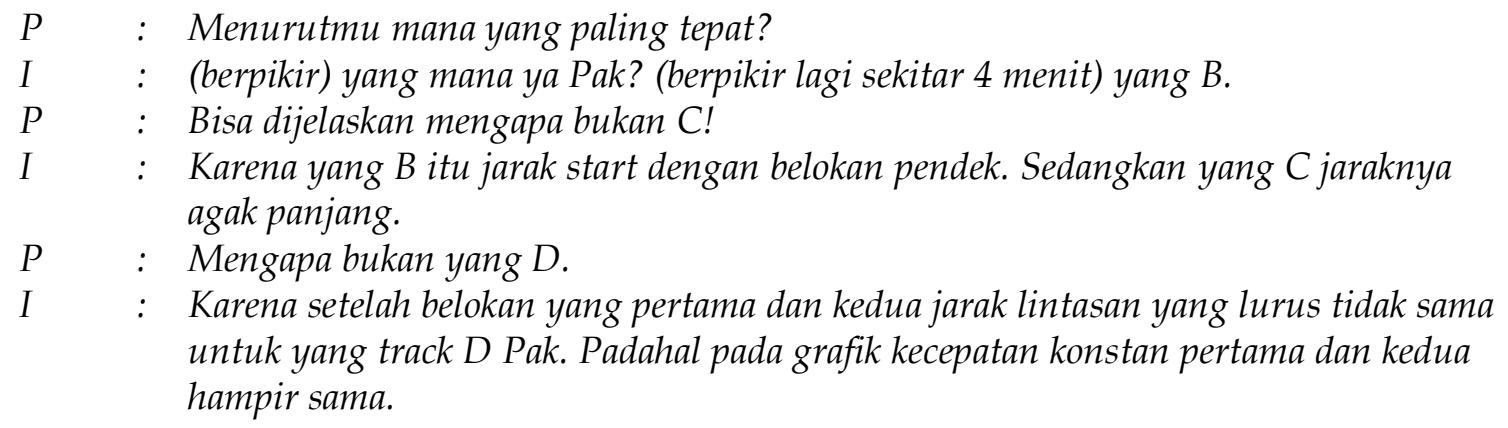

Berdasarkan petikan tersebut terlihat bahwa setelah diberikan sedikit petunjuk sebagaimana pada tahap sebelumnya, S1 mampu menentukan track yang tepat untuk grafik yang diberikan beserta alasannya. Karena S1 mampu menyelesaikan masalah dengan sedikit petunjuk, maka dapat dikatakan terjadi proses modifikasi skemayang sudah ada supaya skema yang baru bisa diterima dengan baik. Oleh karena itu bisa disimpulkan bahwa pada tahap ini S1 mengalami proses akomodasi.

\section{Memeriksa Kembali}

Proses berpikir pada tahap ini ditunjukkan oleh S1 pada saat menjelaskan alasan memilih lintasan B seperti petikan wawancara pada tahap sebelumnya. S1 juga bisa menunjukkan bahwa $\mathrm{C}$ dan $\mathrm{D}$ bukan pilihan jawaban yang tepat meskipun tracknya memiliki 3 tikungan sebagaimana track B, yaitu dengan mendasarkan informasi jarak start terhadap tikungan pertama yang diperoleh dari grafik yang diberikan. Dengan demikian bisa disimpulkan bahwa pada tahap ini S1 mengalami proses asimilasi.

Masalah 2

Pada masalah 2 subjek dituntut untuk menentukan sketsa grafik tinggi permukaan air terhadap waktu, jika air diisikan pada wadah berbentuk besar di bagian bawah dan kecil pada bagian atas.

\section{Memahami Masalah}

Untuk mengetahui proses berpikir S1 dalam memahami masalah 2 ini, maka peneliti melakukan wawancara dengan subjek, dan berikut adalah hasil petikan wawancaranya.

P : Baik, sekarang kita lanjutkan ke masalah 2. Bisa dijelaskan bagaimana kira-kira sketsa grafiknya?

S1 : Menurut saya tingginya cekung seperti parabola.

$P \quad:$ Maksudnya bagaimana cekung seperti parabola?

S1 : Gimana ya Pak (kelihatan bingung).

Berdasarkan petikan tersebut, terlihat bahwa S1 mengalami kebingungan untuk memahami masalah yang diberikan. S1 tidak bisa secara langsung menerima struktur baru (sketsa grafik dari kasus sebagaimana masalah2) dengan struktur lama yang sudah ada (sketsa grafik ketika gelasnya lurus). Di sini terlihat bahwa S1 mengalami proses akomodasi. 


\section{Merencanakan Strategi}

Pada tahap ini peneliti mengeksplorasi proses berpikir S1 sebagaimana melalui wawancara sebagai berikut.

$P \quad$ : Baik, kan sudah saya beri ilustrasi jika tabungnya lurus, maka grafiknya membentuk garis lurus. Tetapi kalau gelasnya lebar di bawah kan perubahan tinggi air kan tidak sama. Coba dipikirkan lagi kira-kira seperti apa grafiknya?

S1 : Kalau seperti pekerjaan saya ini bagaimana Pak?

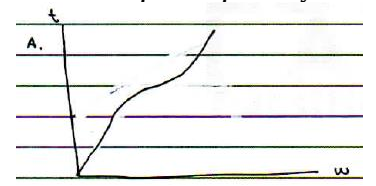

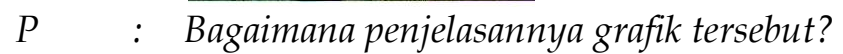

S1 : Maksud saya di grafik itu kecepatan naiknya air tidak tetap Pak, makanya grafiknya agak belak-belok.

$P \quad: \quad$ Coba sekarang semakin ke atas kecepatan naiknya air semakin cepat atau semakin lambat?

S1 : Semakin cepat Pak.

Berdasarkan petikan wawancara tersebut terlihat bahwa sebenarnya S1 mampu membedakan antara grafik jika gelasnya lurus dan gelasnya besar pada bagian bawah. Tetapi dalam membuat sketsa S1 masih terlihat kebingungan. Sehingga pada tahap ini juga bisa disimpulkan S1 mengalami proses akomodasi.

\section{Melaksanakan Strategi}

Berikut adalah jawaban tertulis S1 untuk masalah nomor 2 pada saat mengikuti tes.

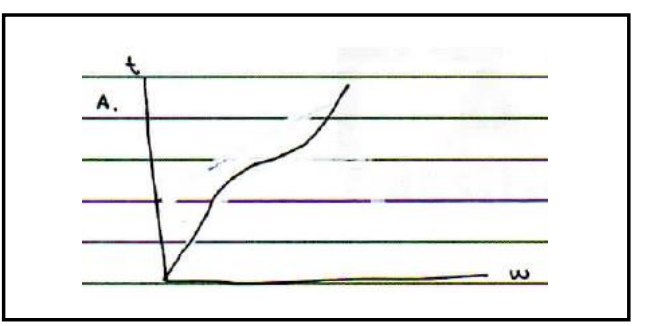

Gambar 2. Jawaban S1 untuk soal nomor 2

Berdasarkan Gambar 2 terlihat bahwa S1 membuat sketsa grafik yang tidak lurus (berbelok), tetapi masih belum tepat jawabannya. Oleh karena itu peneliti ingin mengeksplorasi proses berpikir S1 pada tahap ini melalui wawancara sebagaimana petikan berikut.

$P \quad:$ Oke, kalau semakin cepat berarti tinggi air kan semakin naik dengan cepat pula, artinya semakin tambah waktu semakin cepat pertambahan tingginya. Nah sekarang saya beri ilustrasi untuk $t=1,2,3,4,5$, maka tingginya misalnya $2 ; 3,5 ; 4,5 ; 5 ; 5,25$. Coba buat sketsa grafiknya.

S1 : (membuat sketsa grafik) oiya Pak. Seperti punya saya tadi tetapi bentuknya melengkung mirip setengah grafik parabola.

Sesuai petikan tersebut S1 mampu menjelaskan sketsa grafik yang lebih tepat (mirip dengan setengah grafik parabola) setelah mendapatkan bantuan atau petunjuk. Oleh karena itu bisa dikatakan pada S1 terjadi proses penyesuaian struktur yang lama untuk bisa menerima struktur yang baru. Sehingga disimpulkan pada tahap ini S1 mengalami proses akomodasi. 


\section{Memeriksa Kembali}

Proses berpikir pada tahap ini ditunjukkan oleh S1 pada saat menjelaskan alasan membuat sketsa grafik seperti petikan wawancara pada tahap sebelumnya. Dengan demikian bisa disimpulkan bahwa pada tahap ini S1 mengalami proses akomodasi juga.

Berdasarkan analisis proses berpikir untuk S1 tersebut, bisa disimpulkan bahwa pada tahap memahami masalah terjadi proses akomodasi, pada tahap merencanakan penyelesaian terjadi proses asimilasi dan akomodasi, pada tahap penyelesaian masalah terjadi proses akomodasi, dan pada tahap memeriksa kembali terjadi proses asimilasi dan akomodasi.

\section{Subjek 2 (S2)}

Masalah 1

\section{Memahami Masalah}

Untuk mengetahui proses berpikir S2 dalam memahami masalah, maka dilakukan wawancara dengan subjek MAA, dan berikut adalah hasil petikan wawancaranya.

$P \quad$ : Coba jelaskan grafik yang ada di soal tersebut!

S2 : Jadi grafik ini menyatakan hubungan kecepatan dengan waktu. Jika grafik turun, maka kecepatan juga turun, ini terjadi pada jalan berbelok. Sedangkan grafik naik terjadi ketika kecepatan ditambah, ini terjadi ketika setelah tikungan atau belokan.

$P \quad$ : Pada lintasan lurus apakah grafiknya hanya yang lurus saja?

S2 : Tidak Pak. Yang naik tadi juga terjadi pada jalan lurus setelah tikungan selesai, yaitu ketika pembalap mulai menambah kecepatan di jalan yang lurus.

Berdasarkan petikan tersebut, terlihat bahwa S2 mampu memahami dengan baik masalah yang diberikan. S2 bisa menjelaskan dengan baik makna dari grafik, misalnya grafik menurun menunjukkan jalan/track berbelok. Sedangkan pada track lurus, kecepatan akan meningkat setelah belokan dan turun menjelang belokan. Berarti skema atau struktur baru yang bersumber dari masalah yang diberikan langsung bisa diterima oleh struktur yang sudah ada tanpa melakukan modifikasi. Sehingga bisa dikatakan bahwa pada tahap ini terjadi proses asimilasi.

\section{Merencanakan Strategi}

Pada tahap ini peneliti mengeksplorasi proses berpikir S1 sebagaimana petikan wawancara berikut.

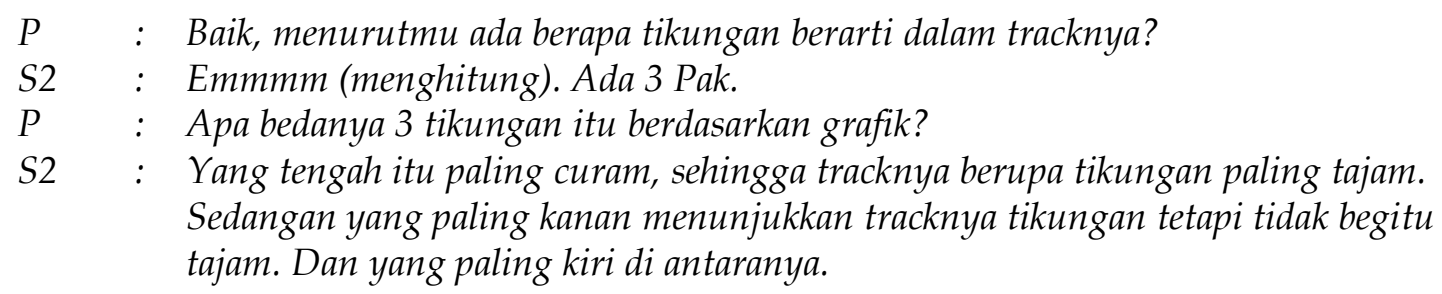

Berdasarkan petikan tersebut S2 bisa menjelaskan banyaknya tikungan pada track dengan mengacu grafik yang diberikan, yaitu tikungan bisa ditentukan dengan melihat grafik yang menurun. S2 juga bisa membedakan perbedaan panjang grafik menurun tersebut, yaitu semakin panjang turunan grafik berarti tikungannya semakin tajam. Hal ini menunjukkan bahwa pada tahap ini S2 mengalami proses asimilasi karena S2 mampu mengkoneksikan struktur yang lama (pemahaman tentang grafik fungsi) dengan struktur yang baru (hubungan grafik kecepatan dengan track balapan). 
Melaksanakan Strategi

Berikut adalah jawaban tertulis S2 untuk masalah 1.

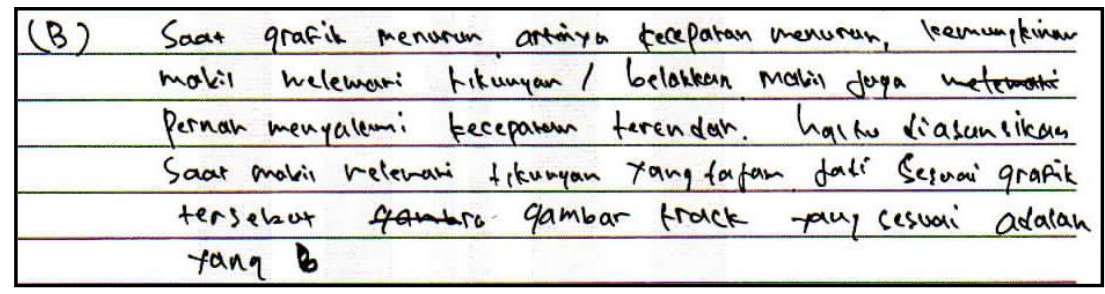

Gambar 3. Jawaban S2 untuk soal nomor 1

Berdasarkan Gambar 3 terlihat bahwa dalam menentukan track yang tepat untuk grafik yang diberikan, S2 mampu melakukan proses pengaitan skema lama dan baru dengan baik, yaitu bisa menjelaskan makna naik turunnya grafik pada bentuk track/lintasan. Sehingga terlihat bahwa pada tahap ini S2 mengalami proses Asimilasi. Hal ini juga didukung dengan hasil wawancara sebagai berikut.

$P \quad:$ Baik, dari grafik tersebut menurutmu track mana yang paling tepat?

S2 : Yang B Pak.

$P \quad$ : Bisa diberi penjelasan mengapa memilih yang B!

S2 : Jadi berdasarkan grafik tadi kan ada 3 tikungan Pak. Nah, berarti jawaban yang mungkin adalah $B, C$, dan D. Yang $C$ tidak saya pilih karena dari start menuju tikungan pertama jaraknya agak jauh, padahal di grafik dari start langsung menurun grafiknya. Sedangkan D juga tidak dipilih karena tikungan yang paling tajam terletakpada tikungan pertama, padahal pada grafik terlihat yang paling curam adalah grafik kedua. Jadi saya memilih yang B Pak.

\section{Memeriksa Kembali}

Proses berpikir pada tahap ini ditunjukkan oleh S2 pada saat menjelaskan alasan memilih lintasan B seperti petikan wawancara pada tahap sebelumnya. S2 juga bisa menunjukkan bahwa $\mathrm{C}$ dan $\mathrm{D}$ bukan pilihan jawaban yang tepat meskipun tracknya memiliki 3 tikungan sebagaimana track $B$, yaitu dengan mendasarkan informasi jarak start terhadap tikungan pertama yang diperoleh dari grafik yang diberikan. Dengan demikian bisa disimpulkan bahwa pada tahap ini S2 mengalami proses asimilasi.

Masalah 2

\section{Memahami Masalah}

Untuk mengetahui proses berpikir S2 dalam memahami masalah 2 ini, maka peneliti melakukan wawancara dengan subjek, dan berikut adalah hasil petikan wawancaranya.

$P \quad$ : Sekarang kita lanjutkan masalah yang nomor 2. Coba kamu jelaskan jawabanmu.

S2 : Jadi karena bentuk gelas seperti terompet (lebar di bawah), maka semakin naik permukaan air, kecepatan naiknya juga semakin meningkat. Artinya makin ke atas air makincepat naiknya. Jadi misalnya 1 detik $1 \mathrm{ml}, 2$ detik 2,... ml.

Berdasarkan petikan tersebut, terlihat bahwa S2 mampu mengidentifikasi permasalahan yang diberikan, yaitu mampu menjelaskan informasi yang bisa diperoleh dari soal. Di sini 
terlihat bahwa S2 mengalami proses asimilasi dengan baik pada tahap memahami masalah.

\section{Merencanakan Strategi}

Pada tahap ini peneliti mengeksplorasi proses berpikir S2 sebagaimana wawancara pada tahap memahami masalah di atas. Pada petikan tersebut S2 mampu menjelaskan sketsa grafik yang dibuat dengan diawali pemisalan pertambahan waktu dan pertambahan tinggi permukaan air pada wadah tersebut, sehingga bisa diketahui hubungan keduanya. Hal ini juga menunjukkan bahwa S2 mampu membedakan antara grafik jika gelasnya lurus dan gelasnya besar pada bagian bawah. Sehingga pada tahap ini juga bisa disimpulkan S2 mengalami proses asimilasi.

\section{Melaksanakan Strategi}

Berikut adalah grafik yang dibuat oleh S2 pada saat mengikuti tes beserta penjelasan secara tertulis untuk masalah nomor 2 .

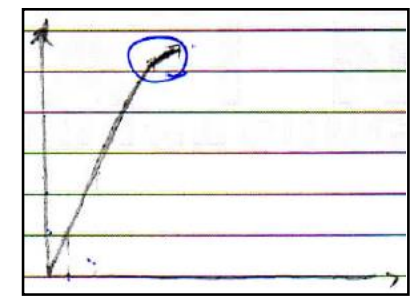

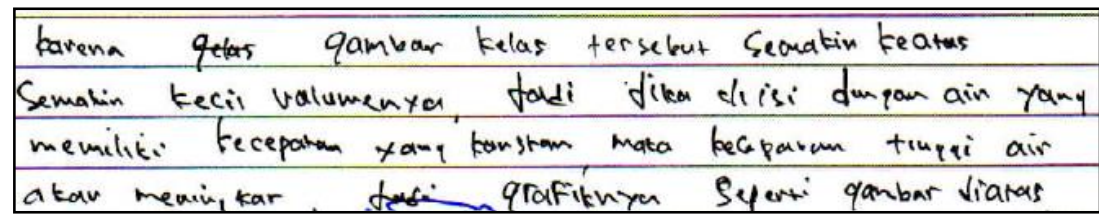

Gambar 4. Jawaban S2 untuk soal nomor 2

Berdasarkan Gambar 4 terlihat bahwa S2 membuat sketsa grafik yang seolah-olah lurus dan berbelok pada ujungnya. Oleh karena itu peneliti ingin mengeksplorasi proses berpikir S2 pada tahap ini melalui wawancara sebagaimana petikan berikut.

P : Grafiknya ini lurus apa tidak?

S2 : Lurus Pak.

$P \quad$ : Coba kamu buat lagi grafiknya yang lebih tepat dengan bantuan ilustrasi tadi,

S2 : (menggambar grafik dalam waktu sekitar 1 menit) seperti ini ya Pak.

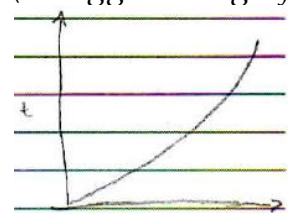

Sesuai petikan tersebut S2 semula berpendapat bahwa grafik yang dibuatnya berupa garis lurus. Tetapi dengan petunjuk dari peneliti yaitu melalui pemisalan waktu dan tinggi air yang dibuat, ternyata S2 mampu menggambar sketsa dengan baik. Hal ini menunjukkan bahwa terjadi proses akomodasi pada tahap menyelesaikan masalah ini.

\section{Memeriksa Kembali}

Proses berpikir pada tahap ini ditunjukkan oleh S2 pada saat S2 menggambar kembali sketsa grafik yang baru melalui pemisalan yang dibuat, dan S2 bisa menyadari 
kesalahan dari grafik yang dibuat pada saat mengikuti tes tulis. Dengan demikian bisa disimpulkan bahwa pada tahap ini S2 mengalami proses akomodasi juga.

Berdasarkan analisis proses berpikir untuk S2 tersebut, bisa disimpulkan bahwa pada tahap memahami masalah terjadi proses asimilasi, pada tahap merencanakan penyelesaian terjadi proses asimilasi, pada tahap penyelesaian masalah terjadi proses asimilasi dan akomodasi, dan pada tahap memeriksa kembali terjadi proses asimilasi dan akomodasi.

Terdapat beberapa teori yang bisa digunakan untuk untuk menganalisis proses berpikir subjek, di antaranya adalah teori asimilasi dan akomodasi, teori pemrosesan informasi, dan teori APOS (action, process, object, scheme). Pada penelitian ini digunakan teori asimilasi dan akomodasi sebagaimana yang diungkapkan oleh Jean Peaget. Ellis (2008) menyatakan bahwa asimilasi merupakan proses merespon suatu informasi baru dengan menyesuaikannya kedalam skema (struktur kognitif) yang sudah ada dalam benak siswa. Asimilasi adalah menyelaraskan antara skema (struktur kognitif) dengan lingkungannya. Senada dengan 2 pendapat tersebut Suparno (2001) menyatakan bahwa asimilasi adalah proses kognitif yang dengannya seseorang mengintegrasikan persepsi, konsep, ataupun pengalaman baru ke dalam skema atau pola yang sudah ada didalam pikirannya. Sedangkan proses akomodasi merupakan pengubahan struktur kognitif, karena tidak atau belum adanya skema-skema tertentu. "Akomodasi terjadi melalui dua hal, yaitu: 1) memodifikasi skema yang telah ada sehingga sesuai dengan infromasi baru, atau 2) membentuk skema baru yang sesuai dengan informasi yang baru" (Ellis, 2008).

"Pembelajaran Matematika mengutamakan keterampilan proses dan strategi dalam menyelesaikan masalah" (Supriadi, dan Subanti, 2015). Siswa dituntut dapat menemukan solusi dalam setiap memecahkan masalah. Hal ini dikarenakan dalam memecahkan masalah diperlukan langkah atau strategi yang baru dan berbeda dibandingkan dengan langkah atau strategi dalam memecahkan masalah yang rutin atau biasa. Siswa akan melakukan proses berpikir untuk menemukan solusi baru dalam pemecahan masalah. Proses berpikir mempunyai peranan yang sangat penting dalam upaya pemecahan masalah. "Dalam proses berpikir terjadi pengolahan antara informasi yang masuk dengan skema (struktur kognitif) yang ada di dalam otak manusia. Pengalaman atau informasi baru yang masuk akan diolah dengan adaptasi melalui proses asimilasi atau akomodasi."

Pada masalah 1 dalam penelitian ini proses asimilasi terjadi ketika subjek mampu menentukan dengan baik sketsa atau bentuk lintasan (track) balapan mobil jika diberikan grafik (hubungan antara jarak tempuh dengan kecepatan). Struktur yang baru (menentukan bentuk lintasan) bisa langsung digabungkan dengan struktur yang lama (pengetahuan tentang cara membaca grafik) jika subjek menguasai dengan baik konsep dan prosedur tentang grafik. Selain itu kemampuan interpretasi grafik juga diperlukan untuk terjadinya proses asimilasi. Sedangkan untuk masalah 2, asimilasi akan terjadi jika struktur yang baru (membuat sketsa grafik tinggi permukaan air terhadap waktu untuk wadah yang melebar dibagian bawah) bisa digabungkan dengan struktur yang lama (pemahaman tentang cara membuat dan membaca grafik fungsi). Asimilasiakan berjalan dengan baik jika subjek sudah memiliki pemahaman yang baik tentang interpretasi grafik, cara membuat grafik, dan cara membaca grafik.

Adapun untuk proses akomodasi, untuk masalah 1 akan terjadi jika subjek mengalami kebingungan menentukan bentuk lintasan balapan jika diberikan grafik hubungan antara kecepatan dengan jarak tempuh. Kebingungan ini disebabkan karena pemahaman yang kurang baik terhadap konsep-konsep dasar mengenai grafik fungsi dan 
interpretasinya. Demikian juga untuk masalah 2, akomodasi akan ditemukan ketika subjek kesulitaan dalam membuat sketsa grafik dari masalah yang diberikan. Pemberian bantuan seperlunya kepada subjek ternyata membantu dalam proses akomodasi. Sehingga pengetahuan atau struktur yang baru akan segera bisa digambungkan dengan struktur yang lama.

Proses berpikir mempunyai peranan yang sangat penting dalam upaya pemecahan masalah. Sebagaimana pendapat yang dikemukakan Carson (2007:7) "Problem solving theory and practice suggest that thinking is more important to solving problems than knowledge and that it is possible to teach thinking in situations where little or no knowledge of the problem is needed". Dalam teori dan praktek "pemecahan masalah menunjukkan bahwa berpikir sangat penting untuk pemecahan masalah daripada sekedar pengetahuan dan dimungkinkan untuk mengajarkan berpikir pada situasi dimana ada atau tidaknya pengetahuan tentang masalah yang diperlukan." Carson (2007:12) berpendapat bahwa "Thinking is actually the integration of theory and practice, the abstract and the concrete, the conceptual and the particular". Berpikir sebenarnya "merupakan penggabungan antara teori dan praktek, abstrak dan konkret, konsep dan fakta." Proses berpikir yang terjadi dalam benak siswa akan berakhir sampai diketemukan jawaban. "Proses atau jalannya berpikir itu ada tiga langkah, yaitu: (1) pembentukan pengertian, (2) pembentukan pendapat, dan (3) penarikan kesimpulan. Mengetahui proses berpikir siswa dalam menyelesaikan suatu masalah matematika sangat penting bagi guru. Guru harus memahami cara berpikir siswa dan mengolah informasi yang masuk sambil mengarahkan siswa untuk mengubah cara berpikirnya jika itu ternyata diperlukan. Guru harus mengetahui proses berpikir siswa dalam memecahkan masalah supaya pembelajaran yang direncanakan dapat berhasil dan meraih hasil maksimal."

Pada setiap tahapan langkah pemecahan masalah menggunakan model Polya, ternyata proses berpikir subjek yang meliputi asimilasi dan akomodasi terjadi secara silih berganti. Ada subjek yang pada tahap memahami masalah dan merencanakan strategi mengalami proses asimilasi, tetapi pada tahap melaksanakan strategi dan memeriksa kembali mengalami proses akomodasi. Ada juga sebaliknya pada tahap memahami masalah dan merencanakan strategi mengalami proses akomodasi, tetapi pada tahap melaksanakan strategi dan memeriksa kembali mengalami proses asimilasi. Di samping itu ada juga subjek yang proses berpikirnya cenderung kepada asimilasi saja atau akomodasi saja (hasil selengkapnya bisa dilihat pada Tabel 4.1). Hal ini sesuai Pendapat Suparno (2001) yang menyatakan bahwa "proses asimilasi dan akomodasi diperlukan dalam pengembangan kognitif seseorang. Sehingga diperlukan keadaan seimbang antara proses asimilasi dan akomodasi." Proses tersebut dinamakan equilibrium, yaitu pengaturan diri mekanis (mechanical self-regulation) yang perlu untuk mengatur keseimbangan proses asimilasi dan akomodasi. Jika tidak seimbang dinamakan disekuilibrium. Ketika keadaan tidak seimbang diperlukan proses ekuilibrasi, yaitu proses bergerak dari keadaan disekuilibrium ke ekuilibrium. Ekuilibrasi membuat seseorang dapat menyatukan pengalaman luar dengan struktur dalam otak.

\section{SIMPULAN}

Langkah-langkah penyelesaian masalah berstandar PISA yang dilakukan mahasiswa meliputi: (a) memahami masalah: yaitu mahasiswa mampu merumuskan apa yang diketahui dan apa yang ditanyakan dari permasalahan; (b) merencanakan strategi: yaitu mahasiswa mampu menyusun strategi pemecahan masalah sesuai dengan prosedur yang tepat, sehingga dapat membantu untuk memperoleh solusi pemecahan masalah matematis, (c) melaksanakan strategi: yaitu mahasiswa mampu melaksanakan strategi pemecahan masalah matematis dengan perhitungan yang tepat; dan (d) memeriksa 
kembali: yaitu mahasiswa memeriksa proses dan hasil yang diperoleh, serta tepat dalam menarik solusi. Proses berpikir mahasiswa ketika menyelesaikan masalah berstandar PISA meliputi: (a) asimilasi: yaitu mahasiswa dapat menerapkan secara langsung pengetahuan yang dimilikinya dengan masalah yang ada untuk memperoleh solusi permasalahan; dan (b) akomodasi: yaitu mahasiswa memodifikasi pengeta-huan yang dimilikinya untuk disesuaikan dengan masalah yang ada serta membentuk pengetahuan baru untuk disesuaikan dengan masalah yang ada.

Bagi peneliti lain yang berminat bisa melaksanakan penelitian tentang proses berpikir dalam menyelesaikan masalah PISA ini menggunakan teori asimilasi dan akomodasi dalam analisisnya, diharapkan penelitian yang akan datang bisa digunakan teori lain sebagai dasar analisisnya, misalnya Teori APOS, Teori pemrosesan informasi, dan sebagainya.

\section{UCAPAN TERIMA KASIH}

Peneliti menyampaikan ucapan terimakasih yang sebesar-besarnya kepada Kementerian Agama Republik Indonesia yang telah membiayai penelitian ini melalui dana BOPTN tahun 2018. Ucapan terimakasih juga kami sampaikan kepada segenap jajaran pimpinan IAIN Tulungagung yang sudah memfasilitasi dan mendukung proses penelitian ini.

\section{DAFTAR PUSTAKA}

Carson, J. (2007). A Problem With Problem Solving, Teaching Thinking Without Teaching Knowledge. Journal of The Mathematics Educator (2007), Vol. 17, No. 2, 7-14.

Creswell, J.W. (2012). Qualitative, quantitative, and mixed methods approaches: Third edition. California: SAGE Publications.

Dewiyani. (2008). Mengajarkan Pemecahan Masalah dengan Menggunakan Langkah Polya. 88 Stikom Jurnal, Volume 12 Nomor 2.

Ellis, Nick C. (2008). Usage-based and form-focused language acquisition: The associative learning of constructions, learned-attention, and the limited L2 endstate. In Handbook of cognitive linguistics and second language acquisition, edited by P. Robinson and N. C. Ellis. London: Routledge.

Hayat, B \& Yusuf, S. (2010). Benchmark Internasional Mutu Pendidikan. Jakarta : Bumi Aksara

Johar, R. (2012). Domain Soal PISA untuk Literasi Matematika. Jurnal Peluang Volume 1 No 1 Universitas Syiah Kuala. Aceh.

Ketut Suma, I Gusti Putu Sudiarta, Ida Bagus Putu Arnyana, I Nengah Martha. (2007). Pengembangan Keterampilan Berpikir Divergen Melalui Pemecahan Masalah Matematika-Sains Terpadu Open-Ended Argumentatif. Jurnal Pendidikan dan Pengajaran, 40(4). 800-816.

Lazakidou, G. (2007). The transitory phase to the attainment of self-regulatory skill in mathematical problem solving. International Education Journal 8(1). 71-81. Shannon Research Press.

OECD. (2012). PISA 2012 Mathematics Framework diunduh dari http://www.oecd.org/dataoecd/61/15/46241909.pdf pada tanggal 3 Maret 2016. 
Suparno, Paul. (2001).Teori Perkembangan Kognitif Jean Piaget, Yogyakarta: Penerbit Kanisius.

Supriadi, D.M \& Subanti, Sri. (2015). Analisis Proses Berpikir Siswa Dalam Memecahkan Masalah Matematika Berdasarkan Langkah Polya Ditinjau dari Kecerdasan Emosional Siswa Kelas VII SMP Al-Azhar Syifa Budi Tahun Pelajaran 2013/2014. Jurnal Elektronik Pembelajaran Matematika. PPS Universitas Sebelas Maret Surakarta.

Suryabrata, Sumadi. (2004). Psikologi Pendidikan. Jakarta: PT Rajagrafindo Persada.

Wardhani, S., Rumiati. (2011). Instrumen Penilaian Hasil Belajar Matematika SMP: Belajar dari PISA dan TIMSS. Yogyakarta: P4TK Matematika.

Yulaelawati, Ella. (2004). Kurikulum dan Pembelajaran filosofi teori dan Aplikasi. Pakar Raya Pustaka. Bandung.

Zhu, Z. (2007). Gender differences in Mathematical Problem Solving Patterns: A Review of Literatur. International Education journal, 8 (2). 187-203. Shannon Research Press. 